\title{
Kinetics and Mechanism of Oxidation of Sodium Sulfanilate by Dihydroxydiperiodat Onickelate(IV) in Aqueous Medium
}

\author{
Haixia Shen, Jinhuan Shan, Jiying Zhang \& Xiaoqian Wang \\ College of Chemistry and Environmental Science, Hebei University \\ Baoding 071002, China \\ E-mail: shanjinhuaner@yahoo.com.cn
}

\begin{abstract}
The kinetics of oxidation of sodium sulfanilate by dihydroxydiperiodatonickelate(IV)(DPN) was studied spectrophotometrically in alkaline medium. The reaction rate showed first order dependence in oxidant and fractional order in reductant. The corresponding reaction mechanism involving a pre-equilibrium of adduct formation between the complex and reductant was proposed. The rate equations derived from mechanism can explain all experimental observations. The activation parameters along with rate constants of the rate-determining step were calculated.
\end{abstract}

Keywords: Dihydroxydiperiodatonickelate(IV), Sodium sulfanilate, Oxidation, Kinetics and mechanism

\section{Introduction}

In recent years, the study of the highest oxidation state of transition metals has intrigued many researchers. This can provide new and valuable information in some fields. Transition metals in a higher oxidation state can generally be stabilised by chelation with suitable polydentate ligands. Metal chelates such as diperiodatocuprate(III) (Niu, W. J., Zhu, Y., Hu, K. C., Tong, C. L. and Yang, H. S. 1996, p.899-904), diperiodatoargentate(III) (Shi, T. S. 1990, p.471-479 ) and diperiodatonickelate(IV) (Chandraiah, U., Murthy, C. P. and Sushama, K. 1989, p.162-164) are good oxidants in a medium with an appropriate $\mathrm{pH}$ value. $\mathrm{Ni}(\mathrm{IV})$ complexes have been employed as oxidizing agents for the investigation of some organic compounds such as tetrahydrofurfuryl alcohol (Li, Z. T., Wang, F. L. and Wang, A. Z. 1992, p.933-941), L-leucine (Mahesh, R. T., Pol, P. D. and Nandibewoor, S. T. 2003, p.1341-1352), 4-hydroxycoumarin (Shettar, R. S. and Nandibewoor, S. T. 2005, p.137-143), gabapentin (Hiremath, C. V., Hiremath, D. C. and Nandibewoor, S. T. 2007, p.246-253)etc.

Sodium sulfanilate(SS) is an important and interesting compound, which finds a number of applications in the syntheses of organic dyes, resist agent and whitening agent. It can be used as pesticide to control wheat rust disease. In addition, SS is also an ideal material intermediate for perfume, food additive pigment, pharmaceutical and building materials. The study of SS becomes important because of its biological significance. In this paper, the kinetics and mechanism of oxidation of sodium sulfanilate by dihydroxydiperiodatonickelate(IV) is presented.

\section{Experimental}

\subsection{Reagents and instrumentation}

All the reagents used were of A.R. grade. All solutions were prepared with doubly distilled water. The solution of oxidation was prepared (Baker, L. C. W., Mukerjee, H. G. and Sarkar, S. B. and Choudhury, B. K. 1982, p.618-619) and standardized (Murthy, C. P., Sethuram, B. and Rao, T. 1986, p.1212-1218) by the method reported earlier. Its UV spectrum were found to be consistent with that reported in the literature. The concentration of DPN was derived from its absorption at $410 \mathrm{~nm}$. The solution of oxidation was always freshly prepared before use. The ionic strength $\mu$ was maintained by adding $\mathrm{KNO}_{3}$ solution and the $\mathrm{pH}$ of the reaction mixture was adjusted with a $\mathrm{KOH}$ solution. The kinetic measurements were performed on a UV-vis spectrophotometer (TU-1901, Beijing Puxi Inc., China), which had a cell holder kept at constant temperature $\left( \pm 0.1^{\circ} \mathrm{C}\right)$ by circulating water from a thermostat (BG-chiller $\mathrm{E}_{10}$, Beijing Biotech Inc., Beijing).

\subsection{Kinetics measurements}

All kinetics measurements were carried out under pseudo-first order conditions. $2 \mathrm{ml}$ of the oxidation solution containing a definite concentration of $\mathrm{Ni}(\mathrm{IV}), \mathrm{OH}^{-}, \mathrm{IO}_{4}^{-}$was transferred to upper branch of the $\lambda$-type tube and $2 \mathrm{ml}$ of SS solution with an appropriate concentration was transferred separately to the lower branch of this tube. After thermal equilibration at the desired temperature in a thermostat, the two solutions were mixed well and immediately 
transferred into a $1 \mathrm{~cm}$ thick rectangular quartz cell in a constant temperature cell-holder $\left( \pm 0.1^{\circ} \mathrm{C}\right)$. The reaction process was monitored automatically by recording with a TU-1900 spectrophotometer. All other species did not absorb significantly at this wavelength. Details of the determinations are described elsewhere(Shan, J. H., Wang, L. P., Shen S. G. and Sun H. W. 2003, p.265-272).

\section{Results and discussion}

\subsection{Evaluation of pseudo-first order rate constants}

Under the conditions of $[\mathrm{SS}]_{0}>>[\mathrm{Ni}(\mathrm{IV})]_{0}$, the plots of $\ln \left(A_{t}-A_{\infty}\right)$ versus time were straight lines, details of the evaluation are described in our previous work(Qian, J., Gao, M. Z., Shan, J. H. Shen, S. G. and Sun H. W. 2003, p.248-249).

\subsection{The dependence of rate on the concentration of SS}

At constant temperature, $k_{\mathrm{obs}}$ values increase by increasing the concentration of SS while keeping the concentration of $[\mathrm{Ni}(\mathrm{IV})],\left[\mathrm{OH}^{-}\right],\left[\mathrm{IO}_{4}^{-}\right]$, and $\mu$ constant. The order with respect to SS was fractional (Figure 1$)$. The plots of $1 / k_{\mathrm{obs}}$ versus 1/[SS] were straight lines with a positive intercept(Figure $1 \mathrm{r} \geq 0.997$ ) (Figure $2 \mathrm{r} \geq 0.996$ ).

\subsection{The dependence of rate on the concentration of $\mathrm{IO}_{4}^{-}$}

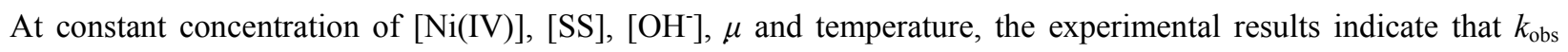
decreases while increasing the concentration of $\left[\mathrm{IO}_{4}^{-}\right]$. The order with respect to $\left[\mathrm{IO}_{4}^{-}\right]$was negative fractional and the plot of $1 / k_{\text {obs }}$ versus $\left[\mathrm{IO}_{4}^{-}\right]$was linear (Figure $\left.3 \mathrm{r}=0.999\right)$ (Figure $\left.4 \mathrm{r}=0.997\right)$.

\subsection{The dependence of rate on the concentration of $\mathrm{OH}^{-}$}

At constant [Ni(IV)], [SS], [ $\left[\mathrm{IO}_{4}^{-}\right], \mu$ and temperature, $k_{\mathrm{obs}}$ values decreased rapidly with the increase in $\left[\mathrm{OH}^{-}\right]$, and then increased slowly with the increase in $\left[\mathrm{OH}^{-}\right]$, The concentration of $\mathrm{OH}^{-}$was about $0.0569 \mathrm{~mol} \cdot \mathrm{L}^{-1}$ at the turning point in which the rate was the slowest.(Table 1).

\subsection{The dependence of rate on the ionic strength}

With other conditions fixed, the reaction rate increased with increase in ionic strength when SS was oxidized by $\mathrm{Ni}(\mathrm{IV})$, indicating that there was a positive salt effect to sodium sulfanilate (Table 2).

\subsection{Discussion of the reaction mechanism}

In alkaline solution, equilibria (1-3) were observed and the corresponding equilibrium constants at $298.2 \mathrm{~K}$ were determined by Aveston(Aveston, J. 1969, p.273-275).

$$
\begin{array}{ll}
2 \mathrm{IO}_{4}{ }^{-}+2 \mathrm{OH}^{-} \rightleftharpoons \mathrm{H}_{2} \mathrm{I}_{2} \mathrm{O}_{10}{ }^{4-} & \log \beta_{1}=15.05 \\
\mathrm{IO}_{4}{ }^{-}+\mathrm{OH}^{-}+\mathrm{H}_{2} \mathrm{O} \rightleftharpoons \mathrm{H}_{3} \mathrm{IO}_{6}{ }^{2-} & \log \beta_{2}=6.21 \\
\mathrm{IO}_{4}{ }^{-}+2 \mathrm{OH}^{-} \rightleftharpoons \mathrm{H}_{2} \mathrm{IO}_{6}{ }^{3-} & \log \beta_{3}=8.67
\end{array}
$$

The distribution of all species of periodate in alkaline solution can be calculated from the equilibriums (1)-(3). The dimer $\mathrm{H}_{2} \mathrm{I}_{2} \mathrm{O}_{10}{ }^{4-}$ and $\mathrm{IO}_{4}{ }^{-}$species can be neglected, the main iodic acid species is $\mathrm{H}_{3} \mathrm{IO}_{6}{ }^{2-}$ and $\mathrm{H}_{2} \mathrm{IO}_{6}{ }^{3-}$. According to the literature, the main existent form of oxidant was $\left[\mathrm{Ni}(\mathrm{OH})_{2}\left(\mathrm{H}_{2} \mathrm{IO}_{6}\right)_{2}\right]^{4-}$ over the experimental concentration range of $\mathrm{OH}^{-}$.

Neglecting the concentration of ligand dissociated from $\mathrm{Ni}(\mathrm{IV})$, the main species of periodate are $\mathrm{H}_{2} \mathrm{IO}_{6}{ }^{3-}$ and $\mathrm{H}_{3} \mathrm{IO}_{6}{ }^{2-}$, here:

$$
\left[\mathrm{IO}_{4}^{-}\right]_{\mathrm{t}} \cong\left[\mathrm{H}_{3} \mathrm{IO}_{6}{ }^{2-}\right]+\left[\mathrm{H}_{2} \mathrm{IO}_{6}{ }^{3-}\right]
$$

Equations (5) and (6) can be obtained from (2), (3), (4):

$$
\begin{aligned}
& {\left[\mathrm{H}_{2} \mathrm{IO}_{6}^{3-}\right]=\frac{\beta_{3}\left[\mathrm{OH}^{-}\right]}{\beta_{3}+\beta_{3}\left[\mathrm{OH}^{-}\right]} \cdot\left[\mathrm{IO}_{4}^{-}\right]_{\mathrm{t}}=f\left(\left[\mathrm{OH}^{-}\right]\right) \cdot\left[\mathrm{IO}_{4}^{-}\right]_{\mathrm{t}}} \\
& {\left[\mathrm{H}_{3} \mathrm{IO}_{6}^{2-}\right]=\frac{\beta_{2}}{\beta_{2}+\beta_{3}\left[\mathrm{OH}^{-}\right]} \cdot\left[\mathrm{IO}_{4}^{-}\right]_{\mathrm{t}}=\phi\left(\left[\mathrm{OH}^{-}\right]\right) \cdot\left[\mathrm{IO}_{4}^{-}\right]_{\mathrm{t}}}
\end{aligned}
$$

Here, $\left[\mathrm{IO}_{4}^{-}\right]_{\mathrm{t}}$ represents the concentration of original over all periodate ions which is approximately equal to the sum of $\left[\mathrm{H}_{2} \mathrm{IO}_{6}{ }^{3-}\right]$ and $\left[\mathrm{H}_{3} \mathrm{IO}_{6}{ }^{2-}\right]$. In the $\left[\mathrm{OH}^{-}\right]$range used in this work, the main specie of periodate is $\mathrm{H}_{2} \mathrm{IO}_{6}{ }^{3-}$. Based on the discussion, the formula of the $\mathrm{Ni}(\mathrm{IV})$ periodate complex may be represented by either $\left[\mathrm{Ni}(\mathrm{OH})_{2}\left(\mathrm{H}_{3} \mathrm{IO}_{6}\right)_{2}\right]^{2-}$ or 
the less protonated ionic species $\left[\mathrm{Ni}(\mathrm{OH})_{2}\left(\mathrm{H}_{2} \mathrm{IO}_{6}\right)_{2}\right]^{4-}$. We preferred to use the latter to represent DPN because it is close to that suggested by Mukherjee(Mukherjee, H. G., Mandal, B. and De, S. 1984, p.426-428).

Based on the above discussion, two simultaneous reaction mechanisms were proposed:

Mechanism I: In a less alkaline medium:

$$
\begin{aligned}
& {\left[\mathrm{Ni}(\mathrm{OH})_{2}\left(\mathrm{H}_{2} \mathrm{IO}_{6}\right)_{2}\right]^{4-}+\mathrm{OH}^{-} \rightleftharpoons K_{1} \rightleftharpoons} \\
& \left(\mathrm{NPN}(\mathrm{OH})_{2}\left(\mathrm{HIO}_{6}\right)\right]^{2-}+\mathrm{H}_{2} \mathrm{IO}_{6}^{3-}+\mathrm{H}_{2} \mathrm{O} \\
& \mathrm{NH}_{2} \mathrm{C}_{6} \mathrm{H}_{6} \mathrm{SO}_{3}^{-}\left(\mathrm{or} \mathrm{R}^{-}\right)+\mathrm{H}_{2} \mathrm{O} \rightleftharpoons K_{2} \rightleftharpoons \mathrm{NH}_{3}{ }^{+} \mathrm{C}_{6} \mathrm{H}_{6} \mathrm{SO}_{3}^{-}+\mathrm{OH}^{-} \\
& {\left[\mathrm{Ni}(\mathrm{OH})_{2}\left(\mathrm{HIO}_{6}\right)\right]^{2-}+\mathrm{NH}_{3}{ }^{+} \mathrm{C}_{6} \mathrm{H}_{6} \mathrm{SO}_{3}^{-} \stackrel{K_{3}}{\longrightarrow} \text { complex }}
\end{aligned}
$$

$(\mathrm{MPN})$

$$
\text { complex } \stackrel{k}{\longrightarrow} \mathrm{Ni}(\mathrm{II})+\text { product }
$$

Here, reaction (9) was the rate-determining step.

$$
[\mathrm{Ni}(\mathrm{IV})]_{\mathrm{T}}=[\mathrm{DPN}]_{\mathrm{e}}+[\mathrm{MPN}]_{\mathrm{e}}+[\text { complex }]_{\mathrm{e}}
$$

Subscripts $t$ and e stand for total concentration and concentration at equilibrium respectively.

As the rate of the disappearance of $[\mathrm{Ni}(\mathrm{IV})]_{\mathrm{t}}$ was monitored, the rate of the reaction can be derived as:

$$
\begin{gathered}
-\frac{\mathrm{d}\left[\mathrm{Ni}(\mathrm{IV})_{\mathrm{t}}\right]}{\mathrm{dt}}=\frac{k K_{1} K_{2}\left[\mathrm{OH}^{-}\right]\left[\mathrm{R}^{-}\right]}{K_{1} K_{2}\left[\mathrm{R}^{-}\right]\left[\mathrm{OH}^{-}\right]+K_{1}\left[\mathrm{OH}^{-}\right]+\left[\mathrm{H}_{2} \mathrm{IO}_{6}^{3-}\right]}[\mathrm{Ni}(\mathrm{IV})]_{\mathrm{t}} \\
\therefore k_{\mathrm{obs}}=\frac{k K_{1} K_{2} K_{3}\left[\mathrm{R}^{-}\right]}{K_{1} K_{2} K_{3}\left[\mathrm{R}^{-}\right]+K_{1}\left[\mathrm{OH}^{-}\right]+\left[\mathrm{H}_{2} \mathrm{IO}_{6}^{3-}\right]} \\
\frac{1}{k_{\mathrm{obs}}}=\frac{1}{k}+\frac{K_{1}\left[\mathrm{OH}^{-}\right]+f\left(\mathrm{OH}^{-}\right)\left[\mathrm{IO}_{4}^{-}\right]}{k K_{1} K_{2} K_{3}\left[\mathrm{R}^{-}\right]} \cdot \frac{1}{\left[\mathrm{R}^{-}\right]} \\
\frac{1}{k_{\mathrm{obs}}}=\frac{K_{1} K_{2} K_{3}\left[\mathrm{R}^{-}\right]+K_{1}\left[\mathrm{OH}^{-}\right]}{k K_{1} K_{2} K_{3}\left[\mathrm{R}^{-}\right]}+\frac{f\left(\mathrm{OH}^{-}\right)}{k K_{1} K_{2} K_{3}\left[\mathrm{R}^{-}\right]} \cdot\left[\mathrm{IO}_{4}^{-}\right]
\end{gathered}
$$

Mechanism II. In a more alkaline medium:

$$
\begin{array}{ll}
{\left[\mathrm{Ni}(\mathrm{OH})_{2}\left(\mathrm{H}_{2} \mathrm{IO}_{6}\right)_{2}\right]^{4-+}+\mathrm{OH}^{-} \rightleftharpoons K_{1} \rightleftharpoons} & {\left[\mathrm{Ni}(\mathrm{OH})_{2}\left(\mathrm{HIO}_{6}\right)\right]^{2-}+\mathrm{H}_{2} \mathrm{IO}_{6}{ }^{3-}+\mathrm{H}_{2} \mathrm{O}} \\
(\mathrm{DPN}) & (\mathrm{MPN})
\end{array}
$$

$$
\left[\mathrm{Ni}(\mathrm{OH})_{2}\left(\mathrm{HIO}_{6}\right)\right]^{2-}+\mathrm{NH}_{2} \mathrm{C}_{6} \mathrm{H}_{6} \mathrm{SO}_{3}^{-}\left(\text {or R-) } \stackrel{K_{2}}{\longrightarrow}\right. \text { complex }
$$

(MPN)

$$
\text { complex } \stackrel{k}{\longrightarrow} \mathrm{Ni}(\mathrm{II})+\text { product }
$$

The total concentration of $\mathrm{Ni}(\mathrm{IV})$ at time $\mathrm{t}$ can be written as : 


$$
[\mathrm{Ni}(\mathrm{IV})]_{\mathrm{T}}=[\mathrm{DPN}]_{\mathrm{e}}+[\mathrm{MPN}]_{\mathrm{e}}+[\text { complex }]_{\mathrm{e}}
$$

Since reaction (15) is the rate-determining step, the rate of disappearance of $[\mathrm{Ni}(\mathrm{IV})]_{\mathrm{t}}$ is monitored as:

$$
\begin{gathered}
\therefore k_{\mathrm{obs}}=\frac{k K_{1} K_{2}\left[\mathrm{OH}^{-}\right]\left[\mathrm{R}^{-}\right]}{K_{1} K_{2}\left[\mathrm{R}^{-}\right]\left[\mathrm{OH}^{-}\right]+K_{1}\left[\mathrm{OH}^{-}\right]+\left[\mathrm{H}_{2} \mathrm{IO}_{6}^{3-}\right]} \\
\frac{1}{k_{\text {obs }}}=\frac{1}{k}+\frac{f\left(\left[\mathrm{OH}^{-}\right]\right)\left[\mathrm{IO}_{4}^{-}\right]_{\mathrm{t}}+K_{1}\left[\mathrm{OH}^{-}\right]}{k K_{1} K_{2}\left[\mathrm{OH}^{-}\right]} \cdot \frac{1}{\left[\mathrm{R}^{-}\right]} \\
\frac{1}{k_{\text {obs }}}=\frac{1+K_{2}\left[\mathrm{R}^{-}\right]}{k K_{2}\left[\mathrm{R}^{-}\right]}+\frac{f\left(\left[\mathrm{OH}^{-}\right]\right)}{k K_{1} K_{2}\left[\mathrm{OH}^{-}\right]\left[\mathrm{R}^{-}\right]} \cdot\left[\mathrm{IO}_{4}^{-}\right]_{\mathrm{t}}
\end{gathered}
$$

In this report, Equations (12) and (18) can explain $k_{\text {obs }}$ values decreased rapidly with the increase in [OH'] up to $0.0569 \mathrm{~mol} \cdot \mathrm{L}^{-1}$, after that point, it increased gradually with the continuous increase in $\left[\mathrm{OH}^{-}\right]$. Equations (14) and (20) show that the plots of $1 / k_{\mathrm{obs}}$ versus $\left[\mathrm{IO}_{4}^{-}\right]$should also be linear. Equations (13) and (19) show that the order in SS should be fractional order and $1 / k_{\mathrm{obs}}$ versus $1 /[\mathrm{SS}]$ should be linear. The rate equations derived from the reaction mechanisms are consistent with our experimental results. The activation energy and the thermodynamic parameters were evaluated by the previously published method (Shan, J. H. and Liu, T. Y. 1994, p.1140-1144). (Table 3)

\section{Conclution}

Among various species of $\mathrm{Ni}(\mathrm{IV})$ in alkaline liquids, monoperiodatonickelate is considered as the active species for the title reaction. The rate constant of slow step and other equilibrium constants involved in the mechanism are evaluated and activation parameters with respect to the slow step of the reaction were computed. The overall mechanistic sequence described here is consistent with mechanistic studies and kinetic studies.

\section{References}

Aveston, J. (1969). Hydrolysis of Potassium Periodate: Ultracentrifugation Potentiometric Titration and Raman Spectra. J. Chem. Soc., (A): 273-275.

Baker, L. C. W., Mukerjee, H. G. and Sarkar, S. B. and Choudhury, B. K. (1982). Synthesis \& characterisation of lithium bexaorth periodatonickelate(IV). Indian J. Chem., 21(A): 618-619.

Chandraiah, U., Murthy, C. P. and Sushama, K. (1989). Kinetics of oxidation of lactic,mandelic \& glycollic acids by diperiodatonickelate(IV) in alkaline medium. Indian J. Chem., 28(A), 162-164.

Hiremath, C. V., Hiremath, D. C. and Nandibewoor, S. T. (2007). Ruthenium(III) catalysed oxidation of gabapentin (neurontin) by diperiodatonickelate(IV) in aqueous alkaline medium: A kinetic and mechanistic study. J. Mol. Catal. A: Chem., 269, 246-253.

Li, Z. T., Wang, F. L. and Wang, A. Z. (1992). Kinetics and mechanism of oxidation of tetrahydrofuryl alcohol by dihydroxydiperiodatonickelate(IV) complex in aqueous alkaline medium. Int. J. Chem. Kinet., 24, 933-941.

Mahesh, R. T., Pol, P. D. and Nandibewoor, S. T. (2003). Kinetics and mechanism of oxidation of L-leucine by alkaline diperiodatonickelate(IV): A free radical intervention, deamination, and decarboxylation. Monatsh. Chem., 134, 1341-1352.

Mukherjee, H. G., Mandal, B. and De, S. (1984). Preparation and Studies of the Complex Periodatoferrate(III) Hexahydrare and Periodatonickelate(IV) Monohydrate. Indian J. Chem., 23(A): 426-428.

Murthy, C. P., Sethuram, B. and Rao, T. (1986). Oxidation by tetravalent nickel part 1: kineties of electron transfor from some aliphatic alcoholos to Ni (IV) in aqueoous alkaline media. Z Phys Chem. (Leizig)., 287: 1212-1218.

Niu, W. J., Zhu, Y., Hu, K. C., Tong, C. L. and Yang, H. S. (1996). Kinetics of oxidation of SCN by diperiodatocuprate(III) (DPC) in alkaline medium. Int. J. Chem. Kinet., 28, 899-904.

Qian, J., Gao, M. Z., Shan, J. H. Shen, S. G. and Sun H. W. (2003). Kinetics of Oxidation of ethanolamine by dihydroxydiperiodatonickelate(IV) in alkaline media. J. Guangxi Normal Univ., 21(1): 248-249.

Shan, J. H. and Liu, T. Y. (1994). Kinetics and mechanism of substitution reactions of bis(N,N-diethyldithiocarbamato)alkylxanthatocobalt(III) with dipropylamine and di-n-butylamine in methanol. 


\section{ACTA Chem Sin., 52: 1140-1144.}

Shan, J. H., Wang, L. P., Shen S. G. and Sun H. W. (2003). Kinetics and Mechanism of Oxidation of Some Hydroxy Butyric Acid Salts by Ditelluratocuprate(III) in Alkaline Medium. Turk J. Chem., 27: 265-272.

Shettar, R. S. and Nandibewoor, S. T. (2005). Kinetic, mechanistic and spectral investigations of ruthenium(III)-catalysed oxidation of 4-hydroxycoumarin by alkaline diperiodatonickelate(IV) (stopped flow technique). J. Mol. Catal. A: Chem., 234, 137-143.

Shi, T. S. (1990). Studies of unsual oxidation states of transition metals (I)----kinetics and mechanism of oxidation of potassium thiocyanate by diperiodatoargentate(III) ion in alkaline medium. Sci. China, Ser. B Chem., 12, 471-479.

Table $1 . k_{\text {obs }}$ varying with $\left[\mathrm{OH}^{-}\right]$at $298.2 \mathrm{~K}$

$[\mathrm{Ni}(\mathrm{IV})]=7.83 \times 10^{-6} \mathrm{~mol} / \mathrm{L} ;[\mathrm{SS}]=8.00 \times 10^{-3} \mathrm{~mol} / \mathrm{L} ;\left[\mathrm{IO}_{4}^{-}\right]=2.00 \times 10^{-3} \mathrm{~mol} / \mathrm{L} ; \mu=0.167 \mathrm{~mol} / \mathrm{L}$

\begin{tabular}{|c|c|c|c|c|c|c|c|c|c|}
\hline $10^{2}\left[\mathrm{OH}^{-}\right] /(\mathrm{mol} / \mathrm{L})$ & 1.09 & 1.69 & 3.19 & 4.69 & 5.69 & 6.69 & 8.19 & 9.69 & 10.7 \\
\hline $10^{2} k_{\mathrm{obs}} / \mathrm{s}^{-1}$ & 5.09 & 4.35 & 3.40 & 3.22 & 3.02 & 3.12 & 3.26 & 3.37 & 3.41 \\
\hline
\end{tabular}

Table 2. $k_{\mathrm{obs}}$ varying with ionic strength at $298.2 \mathrm{~K}$

$[\mathrm{Ni}(\mathrm{IV})]=7.83 \times 10^{-6} \mathrm{~mol} / \mathrm{L} ;[\mathrm{SS}]=6.00 \times 10^{-3} \mathrm{~mol} / \mathrm{L} ;\left[\mathrm{OH}^{-}\right]=1.69 \times 10^{-2} \mathrm{~mol} / \mathrm{L} ;\left[\mathrm{IO}_{4}^{-}\right]=2.00 \times 10^{-3} \mathrm{~mol} / \mathrm{L}$

\begin{tabular}{|c|c|c|c|c|c|}
\hline $10 \mu /\left(\mathrm{mol} \cdot \mathrm{L}^{-1}\right)$ & 0.249 & 0.449 & 0.749 & 1.15 & 1.75 \\
\hline $10^{2} k_{\mathrm{obs}} / \mathrm{s}^{-1}$ & 2.06 & 2.60 & 3.05 & 3.53 & 3.68 \\
\hline
\end{tabular}

Table 3. Rate constants $(k)$ and activation parameters of the rate-determining step at $298.2 \mathrm{~K}$

\begin{tabular}{|c|c|c|c|c|c|c|}
\hline \multicolumn{2}{|r|}{$T / \mathrm{K}$} & 293.2 & 298.2 & 303.2 & 308.2 & 313.2 \\
\hline \multirow{2}{*}{$10^{2} \mathrm{k} / \mathrm{s}^{-1}$} & In a less alkaline medium & 2.36 & 3.53 & 6.26 & 8.97 & 15.1 \\
\hline & In a more alkaline medium & 1.92 & 2.84 & 4.69 & 7.08 & 12.7 \\
\hline \multirow{2}{*}{$\begin{array}{c}\text { Thermodynamic } \\
\text { activation } \\
\text { parameters }\end{array}$} & In a less alkaline medium & \multicolumn{5}{|c|}{$\begin{array}{c}E_{\mathrm{a}}=70.97 \mathrm{~kJ} \cdot \mathrm{mol}^{-1}, \Delta H^{\neq}=68.49 \mathrm{~kJ} \cdot \mathrm{mol}^{-1}, \\
\Delta S^{\neq}=-42.64 \mathrm{~J} \cdot \mathrm{K}^{-1} \cdot \mathrm{mol}^{-1}\end{array}$} \\
\hline & In a more alkaline medium & \multicolumn{5}{|c|}{$\begin{array}{c}E_{\mathrm{a}}=71.51 \mathrm{~kJ} \cdot \mathrm{mol}^{-1}, \Delta H^{\neq}=69.03 \mathrm{~kJ} \cdot \mathrm{mol}^{-1}, \\
\Delta S^{\neq}=-42.70 \mathrm{~J} \cdot \mathrm{K}^{-1} \cdot \mathrm{mol}^{-1}\end{array}$} \\
\hline
\end{tabular}

The plots of $\ln k$ vs. 1/T have following intercept (a) slope (b) and relative coefficient (r).

In a less alkaline medium: $\mathrm{a}=25.33 \mathrm{~b}=-8536 \mathrm{r}=0.998$

In a more alkaline medium: $\mathrm{a}=25.33 \mathrm{~b}=-8601 \mathrm{r}=0.99$ 


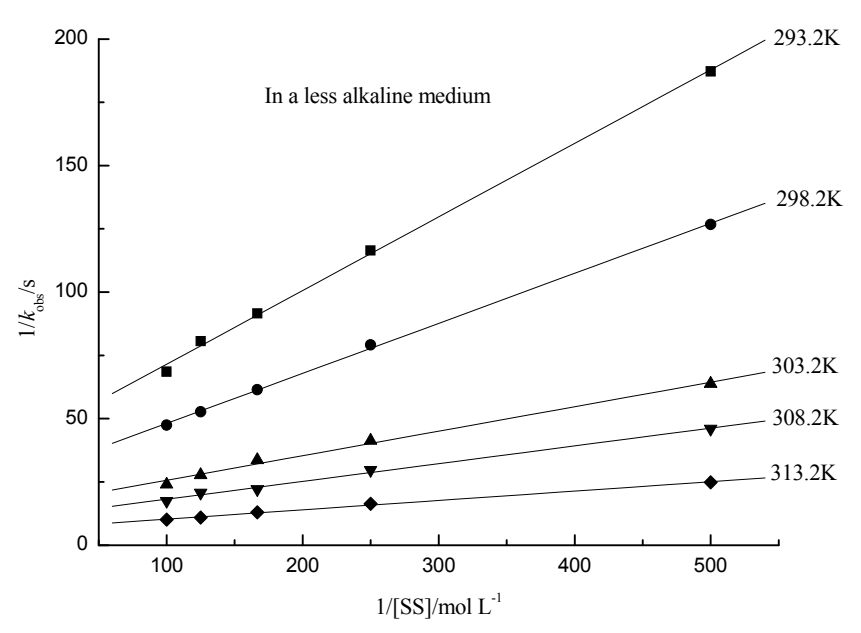

Figure 1. Plots of $1 / k_{\mathrm{obs}}$ versus $1 /[\mathrm{SS}]$ at different temperatures

$[\mathrm{Ni}(\mathrm{IV})]=7.83 \times 10^{-6} \mathrm{~mol} / \mathrm{L} ;\left[\mathrm{OH}^{-}\right]=1.69 \times 10^{-2} \mathrm{~mol} / \mathrm{L} ;\left[\mathrm{IO}_{4}^{-}\right]=2.00 \times 10^{-3} \mathrm{~mol} / \mathrm{L} ; \mu=3.99 \times 10^{-2} \mathrm{~mol} / \mathrm{L}$

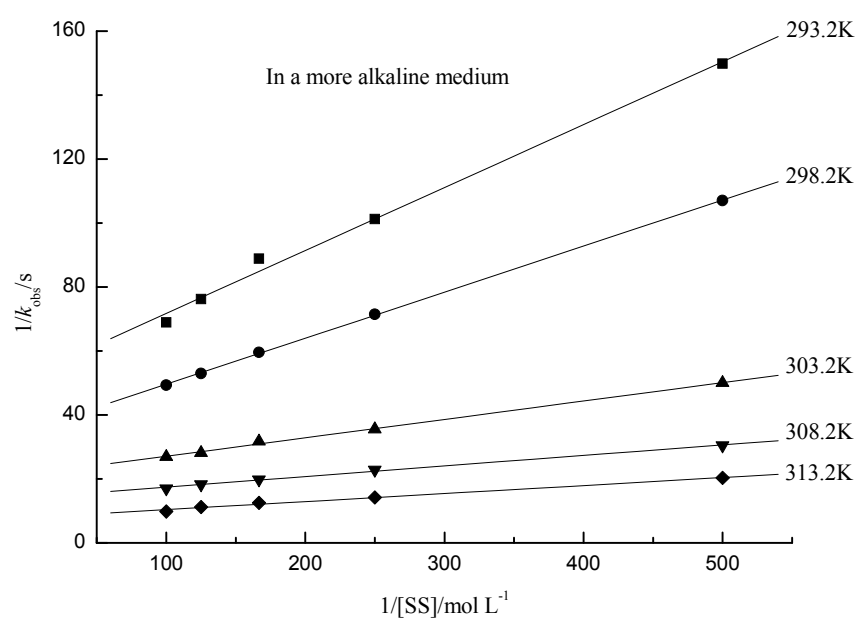

Figure 2. Plots of $1 / k_{\mathrm{obs}}$ versus $1 /[\mathrm{SS}]$ at different temperatures

$[\mathrm{Ni}(\mathrm{IV})]=7.83 \times 10^{-6} \mathrm{~mol} / \mathrm{L} ;\left[\mathrm{OH}^{-}\right]=8.19 \times 10^{-2} \mathrm{~mol} / \mathrm{L} ;\left[\mathrm{IO}^{4-}\right]=2.00 \times 10^{-3} \mathrm{~mol} / \mathrm{L} ; \mu=9.39 \times 10^{-2} \mathrm{~mol} / \mathrm{L}$

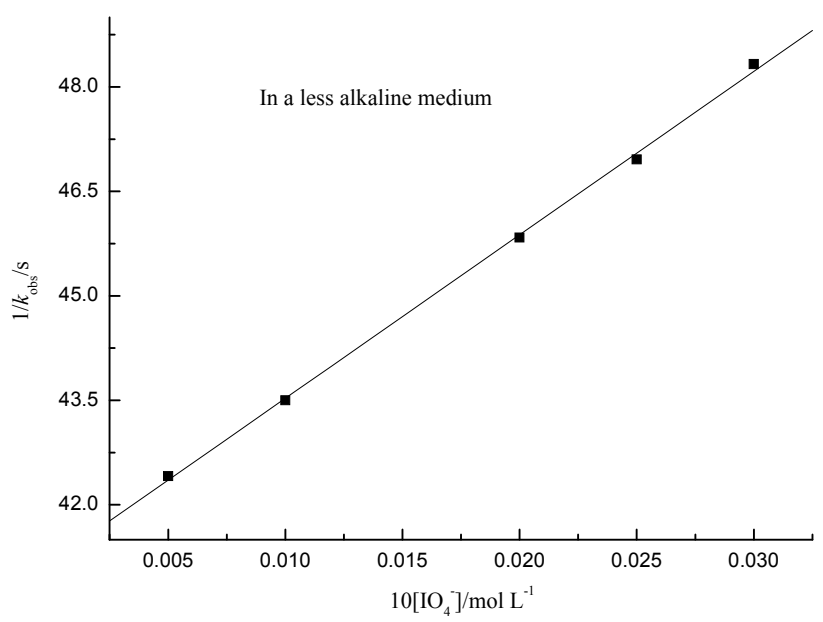

Figure 3. Plot of $1 / k_{\text {obs }}$ versus $\left[\mathrm{IO}^{4-}\right]$ at $298.2 \mathrm{~K}$

$[\mathrm{Ni}(\mathrm{IV})]=7.83 \times 10^{-6} \mathrm{~mol} / \mathrm{L} ;[\mathrm{SS}]=6.00 \times 10^{-3} \mathrm{~mol} / \mathrm{L} ;[\mathrm{OH}-]=1.69 \times 10^{-2} \mathrm{~mol} / \mathrm{L} ; \mu=2.54 \times 10^{-2} \mathrm{~mol} / \mathrm{L}$ 


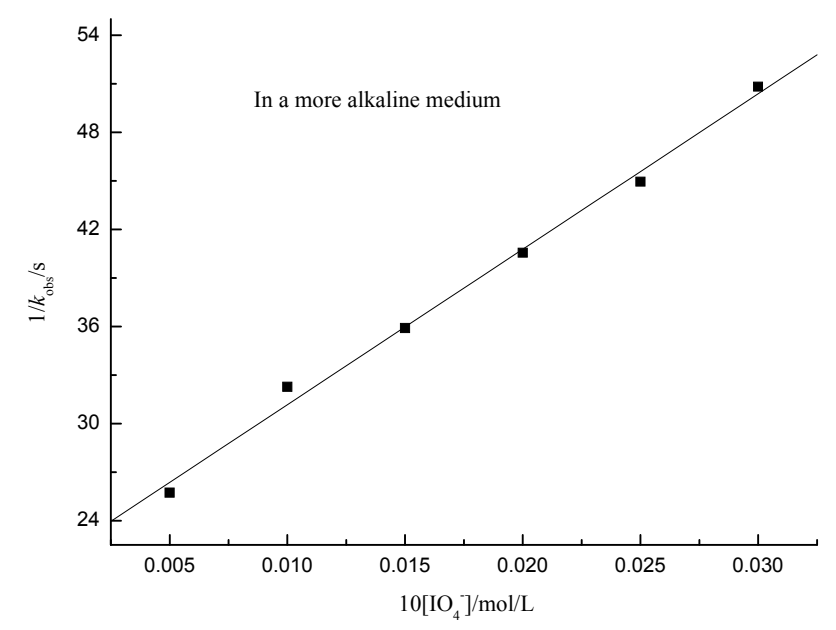

Figure 4. Plot of $1 / k_{\text {obs }}$ versus $\left[\mathrm{IO}^{4-}\right]$ at $298.2 \mathrm{~K}$

$[\mathrm{Ni}(\mathrm{IV})]=7.83 \times 10^{-6} \mathrm{~mol} / \mathrm{L} ;[\mathrm{SS}]=6.00 \times 10^{-3} \mathrm{~mol} / \mathrm{L} ;[\mathrm{OH}-]=8.19 \times 10^{-2} \mathrm{~mol} / \mathrm{L} ; \mu=9.19 \times 10^{-2} \mathrm{~mol} / \mathrm{L}$ 